\title{
Investigation of the Relationship Among Childhood Traumas and Self-Harming Behaviours, Depression, Psychoform and Somatoform Dissociation in Female University Students
}

\author{
Kadın Üniversite Öğrencilerinde Çocukluk Çăğ Travmalar ile Kendine Zarar Verme Davranışlar, Depresyon, \\ Psikoform ve Somatoform Dissosiyasyon Arasindaki İliskilerin Incelenmesi
}

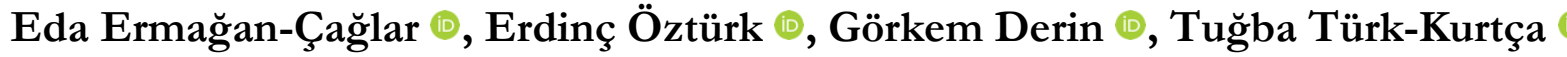

\begin{tabular}{|c|c|}
\hline Authors Information & ABSTRACT \\
\hline $\begin{array}{l}\text { Eda Ermağan-Çağlar } \\
\text { Dr, Embassy of Turkey, Nicosia, } \\
\text { Turkish Republic of Northern Cyprus } \\
\text { eda.e.caglar@northampton.ac.uk } \\
\text { Erdinç Öztürk } \\
\text { Professor, Istanbul University- } \\
\text { Cerrahpaşa, İstanbul, Turkey } \\
\text { erdincerdinc@,hotmail.com } \\
\text { Görkem Derin } \\
\text { Research Assistant, Istanbul } \\
\text { University-Cerrahpaşa, İstanbul, } \\
\text { Turkey gorkem.derin@gmail.com } \\
\text { Tuğba Türk-Kurtça } \\
\text { Dr, Psychological Counselling and } \\
\text { Guidance Depertmant, Trakya } \\
\text { University, Edirne, Turkey } \\
\text { tugbaturk@,trakya.edu.tr }\end{array}$ & $\begin{array}{l}\text { The aim of this study is to determine the predictive role of childhood traumas on self-harming } \\
\text { behaviours, depression, psychoform, and somatoform dissociation in female university } \\
\text { students. This study was conducted with } 314 \text { female university students. It was evaluated that } \\
\text { the differentiation of psychoform dissociation as an independent variable, varied based on } \\
\text { negative or positive taxonomy in terms of dependent variables as well as the predictive effect } \\
\text { of childhood traumas. It was found that childhood trauma predicted psychoform dissociation } \\
\text { experienced in adulthood, and emotional abuse predicted amnestic dissociation, absorption } \\
\text { and psychoform dissociation. The findings of the study differed from other studies, especially } \\
\text { with clinical samples, and childhood traumas were positively correlated with psychoform } \\
\text { dissociation and negatively associated with somatoform dissociation. The findings also } \\
\text { emphasise the importance of certain correlations between childhood trauma and self-harming } \\
\text { behaviours in a non-clinical sample group, such as female university students, as well as } \\
\text { clinical samples. }\end{array}$ \\
\hline Article Information & ÖZET \\
\hline $\begin{array}{l}\text { Keywords } \\
\text { Childhood Trauma } \\
\text { Female University Students } \\
\text { Self-Harming Behaviours } \\
\text { Depression } \\
\text { Dissociation } \\
\text { Somatoform Dissociation } \\
\text { Anahtar Kelimeler } \\
\text { Çocukluk Çağ1 Travmalar1 } \\
\text { Kadın Üniversite Öğrencileri } \\
\text { Kendine Zarar Verme Davranısları } \\
\text { Depresyon } \\
\text { Dissosiyasyon } \\
\text { Somatoform Dissosiyasyon } \\
\text { Article History } \\
\text { Received: } 31 / 01 / 2021 \\
\text { Revision: } 21 / 09 / 2021 \\
\text { Accepted: } 24 / 09 / 2021\end{array}$ & $\begin{array}{l}\text { Bu çalışmanın amacı kadın üniversite öğrencilerinde çocukluk çağı travmalarının; kendine } \\
\text { zarar verme davranışları, depresyon, psikoform ve somatoform dissosiyasyon üzerindeki } \\
\text { yordayıcılık rolünün incelenmesidir. Bu çalısmanın katılımcılarını } 314 \text { kadın üniversite } \\
\text { öğrencisi oluşturmaktadır. Bağımsız değişken olarak psikoform dissosiyasyonun takson } \\
\text { negatif ve pozitif olma durumuna göre bağımlı değişkenler açısından farklılık gösterme } \\
\text { durumu ve çocukluk çağı travmalarının yordayıcılık etkisi değerlendirilmiştir. Çocukluk çağ1 } \\
\text { travmalarının yetişkinlik döneminde yaşanan psikoform dissosiyasyonu, duygusal istismarın } \\
\text { ise amnestik dissosiyasyon, absorbsiyon ve psikoform dissosiyasyonu yordadığ1 } \\
\text { bulgulanmıştır. Çalışma sonucunda, söz konusu bulguların özellikle klinik örneklemli diğer } \\
\text { araştırmalara göre farklılık gösterdiği ve çocukluk çağı travmalarının psikoform dissosiyasyon } \\
\text { ile pozitif yönde, somatoform dissosiyasyon ile ise negatif yönde ilişki gösterdiği saptanmıştır. } \\
\text { Bulgular, ayrıca klinik örneklemlerin yanı sıra kadın üniversite öğrencileri gibi klinik olmayan } \\
\text { bir örneklem grubunda da çocukluk çağı travmaları ile kendine zarar verme davranışları } \\
\text { arasında belirli düzeydeki korelasyonların önemini vurgulamaktadır. }\end{array}$ \\
\hline Counseling and Guldance journal, II(02), 38 & Psychological \\
\hline
\end{tabular}




\section{INTRODUCTION}

The concept of childhood traumas involves any form of neglect, abusive behaviour and similar destructive experiences that are inflicted on an individual during his/her childhood by the primary caregivers, especially the parents, or other individuals in his/her environment (Kepenekçi, 2001). In the relevant literature, these experiences are discussed at the level of abuse such as physical abuse, emotional abuse and/or sexual abuse or at the level of neglect such as physical neglect and emotional neglect (Aysev \& Taner, 2007; Kara, Biçer \& Gökalp, 2004). After the initial studies on the physical and psychological conditions of children working in hazardous works (factories, mines, etc.), in the 19th and 20th centuries, studies focused on the negative effects of childhood abuse and neglect on the physical and psychological health of children and the concept of childhood traumas started to be used in the relevant literature (Marylène, Lisa, \& Lisa, 2006; Türksoy, 2003). Studies in the field also started to discuss the effects of childhood trauma on the individual and they aimed to point out to the effects of childhood traumas on adulthood, sharing the results of psychological consequences in older ages.

Based on the studies in the field, it is known that the traumas experienced in childhood result in an increased inclination toward various psychological disorders in older ages (Vallati et al., 2020). Especially psychological inefficacy, lack of development of self and weak coping skills play a role in the ongoing effects of childhood traumatic experiences. Studies also highlight those traumatic experiences (such as abuse and neglect, etc.) experienced in childhood are risk factors for the development of primary dysfunctional schemas (Carr \& Francis, 2010; McCarthy \& Lumley, 2012; Young, Klosko, \& Weishaar, 2003; Vallati et al., 2020). Said dysfunctional schemas adversely affect the information processing during emotional reactions to the actual life events, entailing significant cognitive problems (such as thought patterns underlying depression) and psychopathologies (Dozois, Martin, \& Bieling, 2009). Öztürk (2018) states that dissociative identity disorder is an effort of self-identification that the individual develops unknowingly as a defence mechanism against chronic childhood traumas. Moreover, the psychohistory discipline, which clearly explains the link between dissociation and individual and social traumas, including the traumatic experiences and negative child rearing styles applied by mothers to their own children, emphasises that it is particularly important to evaluate childhood traumas within the scope of psychologically unhealthy child rearing styles (Öztürk, 2016; 2020a; 2020b).

It is known that the childhood traumas influence an individual in older ages in the form of psychological problems such as decreased self-esteem and socialization, impairment in interpersonal functioning, withdrawal, and self-harm (Gören \& Tiraşç1, 2007; Kahveci, 2016) and observation of behavioural aspects such as decrease in executive functions and increase in impulsivity (Shin et al., 1999; Türksoy, 2003). Along with these effects, the research support that the childhood traumas cause several psychopathologies such as personality disorder, dissociative disorders (Bennet, 2016; Fung et al. 2019), substance addiction, somatoform disorder, anxiety disorder and depression (Bifulco, Brown, \& Adler, 1991; Erdoğan, Delibaş, \& Baskin, 2020; Humphreys et al., 2020; Lindert et al., 2014; Olafson, 2014; Özen, Antar, \& Özkan, 2007; Stein et al.. 1996; Haj-Yahia \& Tamish, 2001; Vallati et al., 2020). In particular, there are various studies highlighting that childhood traumas are key factors in the formation of personality and core beliefs, and are associated with mood disorders. These studies report that psychiatric disorders such as depression (Bifulco et al., 1991) and anxiety disorder (panic disorder and diffuse anxiety) are frequently encountered in adults exposed to sexual abuse in childhood (Stein et al., 1996). Similarly, traumas experienced in childhood increase the risk of self-harming behaviours (Bennet, 
2016; Hoyos et al., 2019), eating disorders (Tunç, 2019), internalized and externalized behaviour problems (Hébert, Langevin, \& Oussaï, 2018) in older ages. It is not possible, or even almost impossible, to react appropriately to both childhood traumas and traumatic events experienced after childhood. This situation, which is called the trauma paradox, creates a feeling of shame in the individual. In the face of the traumatic event, no reaction will be sufficient for the traumatized and dissociated individuals, even if the individuals run away, bow down, freeze, fight or assume that this negative life experience does not exist. The feelings of helplessness and guilt that emerge as a result of the trauma paradox tend to first turn into shame and then into anger. On the traumatic ground, anger is directed towards one's self through self-harming behaviours (Fischer et al., 1996; Öztürk, 2004; 2020a). Some of the psychiatric disorders that are believed to be associated with childhood abuse and neglect are reported as posttraumatic stress disorder (PTSD), cognitive disorders, impairment of self-perception, impairment of interpersonal relationships and psychological health problems (Lindert et al., 2014; Özen et al., 2007). Fonagy and Allison (2012) report that individuals hinder their emotional awareness and display avoidance behaviours because of their traumatic experiences in childhood to safeguard themselves from negative environmental conditions and destructive thoughts. It is highlighted that when individuals lose or hinder their emotion-regulation skills, they reveal their emotions with somatic symptoms rather than verbally. Ogrodniczuk, Joyse and Abbass (2014) also concluded that alexithymia has a mediating role in the relationship between the childhood maltreatment and somatic symptoms.

The term "psychological dissociation", which was founded by Pierre Janet, is used for the psychological components of dissociation, and the term "somatoform dissociation" is used for symptoms that phenomenologically involve the body. Both dissociation terms indicate the lack of integration regarding the individual's responses and functions (Öztürk, 2020b; Van der Hart \& Horst, 1989). Dissociative disorders; are complex and usually co-diagnosed psychiatric disorders, caused by chronic childhood traumas that begin at an early age. Violence-oriented negative child rearing styles are as effective as childhood traumas in the etiopathogenesis of dissociative disorders. Dissociative disorders occur especially after cumulative traumatic experiences encountered in early childhood. (Öztürk, 2020b; 2021). Abuse and neglect in childhood were indicated as significant predictors of dissociation (Terock et al., 2016; Watson et al., 2006). Meta-analysis studies found that childhood abuse/neglect was important in the etiology of dissociation (Merckelbach \& Muris, 2001; Vonderlin et al., 2018). Additionally, studies involving female adults indicate that women report psychological problems related to childhood trauma at higher rates (Abrams, Milisavljević, \& Šoškić, 2019; Chen \& Gueta, 2016; Giarratano, Ford, \& Nochajski, 2020). Fischer et al. (2014) underlined that the prevalence of somatic syndromes in women increases due to the adverse effects of childhood trauma on stress and psychological resilience. The negative experiences of childhood are reported to have a positive relationship with the tendencies of anxious attachment (Waldinger et al., 2006) and the adverse effects of childhood traumas on interpersonal relationships are discussed.

Reviewing the results of childhood traumas in adolescence and adulthood, Gallo et al. (2017) noted that the prevalence of major depression symptoms was three times higher in women compared to men. Similarly, they concluded that individuals exposed to emotional abuse and multiple maltreatment in childhood had a higher risk of experiencing psychological problems in the future compared to men (Gallo et al., 2017). Cutler and Nolen-Hoeksema (1991) took a different approach to depression observed in women. Researchers expressed that women tend to feel ashamed of themselves and take a more introvert attitude because of their experiences under adverse living conditions such as abuse and domestic violence 
and that the risk of low self-confidence and depression increased, accordingly (Cutler \& NolenHoeksema, 1991). It is reported that women with a history of childhood trauma suffer from eating disorders at a higher rate than women without such a history and that they also take considerably more psychiatric medications and psychiatric support (Messina \& Grella, 2006). This study has a unique value as it is one of the first studies investigating childhood traumas and self-harming behaviours, depression, somatoform and psychoform dissociation together in female university students. The aim of this study is to determine the predictive role of childhood traumas on self-harming behaviours, depression, psychoform, and somatoform dissociation in female university students.

\section{METHOD}

\section{Participants and Sample}

The population consists of 143,759 female students who were registered in any undergraduate programme in the academic year 2018-2019 and studied in various departments of Faculty of Education at Trakya University. The sample consists of 314 undergraduate female students, were selected through simple random sampling. In the first phase of the study, researchers applied to the Trakya University Ethics Committee of the Social and Humanities Research and started the data collection process for the research after the ethics decision numbered 2019.01.03 and dated 23/01/2019 was obtained. In the scope of the study, 314 undergraduate female students attending the Faculty of Education were informed about voluntary participation and their informed consents were obtained. Psychiatric diagnosis and/or using medication were not sought in participant selection. The data collection lasted approximately six months. The scales were applied to the participants in return for five extra credits.

314 undergraduate female students were participated in the research. Since the applications were carried out in the classroom, criteria such as psychiatric diagnosis and/or using medication were not sought in participant selection. The mean age of the participants was 19.82 years. Female students who participated in the research were in first $(80.9 \%, \mathrm{n}=254)$, second $(14.6 \%, \mathrm{n}=46)$, third $(2.5 \%, \mathrm{n}=8)$ and fourth $(1.9 \%$, $\mathrm{n}=6$ ) years. When the distribution of their departments was considered, they were studying in the fields of pre-school $(30.3 \%, \mathrm{n}=95)$, psychological counselling and guidance $(28.3 \%, \mathrm{n}=89)$, class-teaching $(19.7 \%, \mathrm{n}=62)$, English $(15 \%, \mathrm{n}=47)$, arts $(2.5 \%, \mathrm{n}=8)$, and special education $(4.1 \%, \mathrm{n}=13)$. Participants stated their income levels as lower-income $(8.9 \%, \mathrm{n}=28)$, middle-income $(88.9 \%, \mathrm{n}=279)$ and highincome level $(2.2 \%, \mathrm{n}=7) .8 .6 \%$ (27) of the participants reported that they had chronic diseases while $91.4 \%$ (287) reported that they did not have any chronic diseases. 25 participants (8.0\%) evaluated their relationship with their mother as "slightly close"; 194 participants $(61.8 \%)$ evaluated as "very close"; 4 participants $(1.3 \%)$ evaluated as "not close at all" and 91 participants $(29.0 \%)$ evaluated as "close". 61 participants (19.4\%) evaluated their relationship with their father as "slightly close"; $117(37.3 \%)$ as "very close"; 22 (7\%) "not close at all" and $114(36.3 \%)$ as "close".

\section{Table 1. Descriptive data on variables}

\begin{tabular}{lccc} 
Variables & $\mathrm{N}$ & $\mathrm{X}$ & $\mathrm{SS}$ \\
Emotional abuse & 314 & 10.18 & 2.12 \\
Physical abuse & 314 & 5.46 & 1.68 \\
Emotional neglect & 314 & 6.08 & 1.95 \\
Physical neglect & 314 & 11.51 & 2.76 \\
Sexual abuse & 314 & 6.04 & 2.82 \\
Minimization & 314 & 1.41 & 1.26 \\
CTQ & 314 & 39.28 & 8.04 \\
\hline
\end{tabular}




\begin{tabular}{lccc}
\hline \hline BDE & & & \\
Amnesia & 314 & 13.13 & 8.60 \\
Absorption & 314 & 3.90 & 4.50 \\
Depersonalisation & 314 & 9.98 & 6.37 \\
DES & 314 & 3.42 & 4.18 \\
Self-Harm & 314 & 21.42 & 16.29 \\
Somatoform & 314 & 7.60 & 11.92 \\
\hline
\end{tabular}

As it can be seen in Table 1, the mean of childhood trauma scores of the entire group was 39.28 $(\mathrm{SD}=8.04)$. The mean scores of emotional abuse (10.18, $\mathrm{SD}=2.12)$, physical abuse (5.46, $\mathrm{SD}=1.68)$, emotional neglect (6.08, $\mathrm{SD}=1.95)$, physical neglect $(11.51, \mathrm{SD}=2.76)$, sexual abuse $(6.04, \mathrm{SD}=2.82)$, and minimization (1.41, $\mathrm{SD}=1.26)$. In addition, the mean scores of $\mathrm{BDI}$, psychoform dissociation, amnesia, absorption, depersonalisation, somatoform dissociation and self-harming behaviour as $13.13(\mathrm{SD}=8.60)$, 21.42 (SD=16.29), 3.90 ( $\mathrm{SD}=4.50), 9.98$ (SD=6.37), $3.42 \quad(\mathrm{SD}=418), 28.81 \quad(\mathrm{SD}=9.32)$ and 7.61 $(\mathrm{SD}=11.9)$.

\section{Ethical Statement}

The authors declare that they continue to work in accordance with scientific study ethics and the Helenski declaration in this study. Accordingly, the research was reviewed by the Trakya University Ethics Committee of the Social and Humanities Research and was given permission (Date: 23/01/2019, Number: 2019.01.03). In addition, the participants participated in the study on a voluntary basis.

\section{Data Collection Tools}

Demographic Information Form. The demographic information form prepared by the researchers included questions asked to determine the characteristics of the participants such as age, department, perceived income level, perceived relationship with mother and perceived relationship with father, history of psychiatric medication use, etc.

Self-Harm Behaviour Inventory (ISAS). It is a self-report inventory developed by Klonsky and Glenn (2009), of which validity and reliability studies were performed. The inventory was developed for a comprehensive assessment of self-harming behaviours without the "intent to commit suicide" and the first part of the inventory investigates 12 different self-harming behaviours (self-cutting, self-biting, carving letters/shapes onto skin, self-burning, pinching, hair-pulling, self-scratching, head-banging/selfhitting or similar, preventing wound healing, skin-rubbing to a hard place, sticking needles into skin, drinking/swallowing hazardous/harmful substances) and associated conditions (frequency of selfharming, age, feeling pain and the desire to stop, etc.). The second part deals with the functions of any such behaviours. In the completed validity-reliability study, the internal consistency of the twelve behaviours was reported to be at a very good level $(\alpha=0.84)$. Bildik et al. (2013) conducted the Turkish validity and reliability study of the inventory and reported it as a valid and reliable tool for evaluating selfharming behaviours. In this study, Cronbach's alpha value was calculated as .95.

Childhood Trauma Questionnaire (CTQ). This assessment tool developed by Bernstein et al. (1994) consists of 28 questions, three of which are items that measure the minimization of trauma. Patients assign a score of 1 to 5 for each item. Using this questionnaire, five sub-scores about childhood sexual, physical, emotional abuse and emotional and physical neglect are obtained, and their combination/sum gives the total score (Bernstein, Fink, \& Handelsman, 1994). The questionnaire, which originally consisted of 53 items, was shortened, and translated into Turkish (Şar, Öztürk, \& İkikardeş, 2012). The 
first translation of the questionnaire, which was re-translated into English by an expert in both languages, was used in a pilot study and the comprehensibility of the items was evaluated and thus, the questionnaire was put into its final form. Consistency was ensured between both versions. The Cronbach's alpha value, which indicates the internal consistency of the questionnaire, was 0.93 for the group of all subjects $(\mathrm{N}=$ 123). Guttmann's split-half coefficient was calculated as 0.97 (S.ar et al., 2012), and the internal consistency coefficient of the scale in this questionnaire was .80 .

Beck Depression Inventory (BDI). This inventory consists of 21 items that measure emotional, somatic, cognitive, and motivational symptoms occurring in depression. Scores are assigned between 0 and 3. The original tool, which was developed in 1961, was revised in 1978. The correlations between the two forms are high (.87-94). In addition, it is frequently used as an external criterion in the validity studies of various measurement tools developed to measure other depression-related structures and variables. Item 2 of the Beck Depression Inventory on pessimism and Item 9 on suicidal thoughts are discussed alone in the analyses of studies on pessimism and suicide. Hisli (1989) adapted said inventory into Turkish. In this study, Cronbach's alpha value was calculated as .86.

Somatoform Dissociation Questionnaire (SDQ). Somatoform dissociation was evaluated by using SDQ. It consists of 20 items measuring analgesia, anesthesia, motor disorders, changing taste/smell preferences, pain, and loss of consciousness (Nijenhuis et al., 1996). This questionnaire developed by Nijenhuis et al. (1998) is used for screening physical dissociation symptoms. Şar et al. (2001) conducted the Turkish validity and reliability study. Cronbach's alpha value was calculated as .88 .

Dissociative Experiences Scale (DES). Psychoform dissociation including the variables about amnesia, loss of control, identity confusion, and fragmentation were evaluated by applying DES to the participants. It is a self-report scale developed by Bernstein and Putnam (1986) and consists of 28 items. For each item of the scale, subjects assign a score of $0-100$, and the result is calculated by taking the average of the total scores. Scores above 30 indicate a possible dissociative disorder. Yargıç, Tutkun and Şar (1995) conducted the Turkish validity and reliability study. In this study, Cronbach's alpha value was .94 .

\section{Procedure}

Data collection was based on questionnaires. The authors introduced the study to the participants, and were available for clarifying questions while the participants filled out the questionnaire. Participation in the study was voluntary. The questionnaires were applied in the classroom and every application took approximately 35 minutes for the participants.

All procedures performed in studies involving human participants were in accordance with the ethical standards of the institutional and/or national research committee and with the 1964 Helsinki declaration and its later amendments or comparable ethical standards.

\section{Data Analysis}

This study was designed based on the relational scanning model. It examined the relationship between childhood traumas and self-harming behaviours, depression, psychoform dissociation and somatoform dissociation evaluated whether variables, except psychoform dissociation, varied based on negative or positive taxonomy in terms of psychoform dissociation as well as the predictive effect of childhood traumas, which is a dependent variable, on other variables. Independent Samples t-Test was used for 
statistical significance among the variables in the study and Pearson's Correlation Coefficient was used to determine the correlation. For Simple Linear Regression analysis, CTQ total score was used as dependent variable and the mean overall DES score and the total BDE and SDQ-20 scores were used as independent variables. Kolmogorov-Smirnov test (K-S) was used to test the normality of data distribution. The distribution was found to be normal ( $\mathrm{p}>.05)$.

\section{RESULTS}

\begin{tabular}{|c|c|c|c|c|c|c|c|c|c|c|c|c|c|c|}
\hline & 1 & 2 & 3 & 4 & 5 & 6 & 7 & 8 & 9 & 10 & 11 & 12 & 13 & 14 \\
\hline Imotional abuse & 1 &, $499^{* *}$ &, $440^{* *}$ &, $529^{* *}$ & ,348** &,$- 431^{* *}$ &, $779^{* *}$ & 009 &, $311^{* *}$ &, $282^{* *}$ &, $229^{* *}$ &, $341^{* *}$ &,- 035 &,$- 151 *$ \\
\hline hy &, $499^{* *}$ & 1 &, $477^{* *}$ & ,290** &, $434^{* *}$ &,$- 259^{* *}$ &, $708^{* *}$ & 039 & ,20 & &, $113^{*}$ & &,- 013 &,- 064 \\
\hline ect &, $440^{* *}$ &, $477^{* *}$ & 1 &, $431^{* *}$ & $39^{* *}$ &,$- 300^{* *}$ &, $690^{* *}$ & ,006 & & &, $113^{*}$ & &,- 066 &,- 067 \\
\hline mo &, $529^{* *}$ &, $290^{* *}$ &, $431^{* *}$ & 1 & ,204** &,$- 696^{* *}$ &, $720^{* *}$ & 058 &, $183^{* *}$ &, $145^{*}$ & $118^{*}$ & $228^{* *}$ &,- 082 &,- 092 \\
\hline ex &, $348^{* *}$ &, $434^{* *}$ &, $239^{* *}$ &, $204^{* *}$ & 1 &,$- 266^{* *}$ &, $661^{* *}$ & ,020 &, 112 & 074 & ,093 & ** & ,016 &,$- 121 *$ \\
\hline &,$- 431^{* *}$ &,$- 259^{* *}$ &,$- 300^{* *}$ &,$- 696^{* *}$ &,$- 266^{* *}$ & 1 &,$- 573^{* *}$ &,- 021 &,$- 175^{* *}$ &,- 093 &,$- 125^{*}$ &,$- 227^{+N a}$ &, $127^{*}$ &, 094 \\
\hline T &, $779^{* *}$ &, $708^{* *}$ &, $690^{* *}$ &, $720^{* *}$ &, $661^{* *}$ &,$- 573^{* *}$ & 1 & ,039 & $267^{* *}$ &, $241^{* *}$ & $185^{* *}$ & 32 &,- 050 &,$- 144^{*}$ \\
\hline e & ,009 &, 039 &, 006 & &, 020 &,- 021 & ,039 & 1 &,- 014 &,- 040 &,- 003 &,- 00 &, $238^{* *}$ &, $406^{* *}$ \\
\hline DES &, $311^{* *}$ & $200^{* *}$ &, $170^{* *}$ &, $183^{* *}$ &, $112^{*}$ &,$- 175^{* *}$ & $267^{* *}$ &,- 014 & 1 &, $869^{* *}$ &, $916^{* *}$ &, $874^{* *}$ &,- 085 &,- 071 \\
\hline $\mathrm{m}$ &, $282^{* *}$ &, $214^{* *}$ &, $190^{* *}$ &, $145^{*}$ &, 074 &,- 093 & $241^{* *}$ &,- 040 &, $869^{* *}$ & 1 &, $674^{* *}$ & ,72 &,- 103 &,- 076 \\
\hline &, $229^{* *}$ &, $113^{*}$ & & & ,093 &,$- 125^{*}$ &, $185^{* *}$ &,- 003 & ,916 &, $674^{* *}$ & 1 &, $716^{* *}$ &,- 053 &,- 037 \\
\hline onalisation &, $341^{* *}$ &, $236^{* *}$ &, $165^{* *}$ & $228^{* *}$ &, $178^{* *}$ &,$- 227^{* *}$ &, $320^{* *}$ &,- 002 &, $874^{* *}$ &, $721^{* *}$ &, $716^{* *}$ & 1 &,- 066 &,- 082 \\
\hline elf-harm &,- 035 &,- 013 &,- 066 &,- 082 & ,016 &, $127^{*}$ &,- 050 &, $238^{* *}$ &,- 085 &,- 103 &,- 053 &,- 066 & 1 &, $183^{* *}$ \\
\hline Somatoform &,$- 151 * *$ & $=-, 064$ &,- 067 &,- 092 &,$- 121 *$ & ,094 &,$- 144 *$ &, $406^{* *}$ &,- 071 &,- 076 &,- 037 &,- 082 &, $183^{* *}$ & 1 \\
\hline
\end{tabular}

**. Correlation is significant at the 0.01 level (2-tailed).

*. Correlation is significant at the $\mathbf{0 . 0 5}$ level (2-tailed).

As it can be seen in Table 2, emotional abuse and physical abuse ( $r=499, \mathrm{p}<.001)$ have a positive significant correlation with physical neglect $(r=, 440, p<.001)$, emotional neglect $(r=, 529, p<.001)$, sexual abuse $(\mathrm{r}=, 348, \mathrm{p}<.001)$, total childhood traumas $(\mathrm{r}=, 779, \mathrm{p}<.001)$, psychoform dissociation $(\mathrm{r}=, 311$, $\mathrm{p}<.001)$, amnestic sub-dimension $(\mathrm{r}=, 282, \mathrm{p}<.001)$, absorption $(\mathrm{r}=, 229, \mathrm{p}<.001)$ and depersonalisation $(\mathrm{r}=, 341, \mathrm{p}<.001)$. They have a negative significant correlation with minimization $(\mathrm{r}=-, 431, \mathrm{p}<.001)$ and somatoform dissociation $(\mathrm{r}=-, 151, \mathrm{p}<.001)$. Physical abuse has a positive correlation with physical neglect $(\mathrm{r}=, 477, \mathrm{p}<.001)$, emotional neglects $(\mathrm{r}=, 290, \mathrm{p}<.001)$, sexual abuse $(\mathrm{r}=.434, \mathrm{p}<.001)$, total childhood trauma $(\mathrm{r}=, 708, \mathrm{p}<.001)$, psychoform dissociation $(\mathrm{r}=.200, \mathrm{p}<.001)$, amnestic sub-dimension $(\mathrm{r}=.214$, $\mathrm{p}<.001)$, absorption $(\mathrm{r}=, 113, \mathrm{p}<.05)$ and depersonalisation $(\mathrm{r}=, 236, \mathrm{p}<.001)$. Physical neglect and emotional neglect $(\mathrm{r}=, 431, \mathrm{p}<.001)$ have a positive correlation with sexual abuse $(\mathrm{r}=, 239, \mathrm{p}<.001)$, total childhood traumas $(\mathrm{r}=.690, \mathrm{p}<.001)$, psychoform dissociation $(\mathrm{r}=.170, \mathrm{p}<.001)$, amnestic sub-dimension $(\mathrm{r}=, 190, \mathrm{p}<.001)$, absorption $(\mathrm{r}=, 113, \mathrm{p}<.05)$ and depersonalisation $(=, 165, \mathrm{p}<.001)$. They have a negative correlation with minimization $(\mathrm{r}=-300, \mathrm{p}<.001)$. Emotional neglect has a positive correlation with sexual abuse $(\mathrm{r}=, 204, \mathrm{p}<.001)$, total childhood traumas $(\mathrm{r}=, 720, \mathrm{p}<.001)$, psychoform dissociation $(\mathrm{r}=, 183, \mathrm{p}<.001)$, amnestic sub-dimension $(\mathrm{r}=145, \mathrm{p}<.05)$, absorption $(\mathrm{r}=, 118, \mathrm{p}<.05)$ and depersonalisation $(\mathrm{r}=, 228, \mathrm{p}<.001)$. It has a negative correlation with minimization $(\mathrm{r}=-, 696, \mathrm{p}<.001)$. Minimization has a positive correlation with absorption $\left(r=-, 125^{*}, r<.05\right)$ and self-harm $(r=, 127, p<.05)$. It has a negative correlation with total childhood traumas $(\mathrm{r}=-, 573, \mathrm{p}<.001)$, psychoform dissociation $(\mathrm{r}=-, 175, \mathrm{p}<.001)$ and depersonalisation $(\mathrm{r}=-, 227, \mathrm{r}<.001)$. Childhood traumas have a positive correlation with psychoform dissociation $(\mathrm{r}=, 267, \mathrm{p}<.001)$, amnestic sub-dimension $(\mathrm{r}=, 241, \mathrm{p}<.001)$, absorption $(\mathrm{r}=, 185, \mathrm{p}<.001)$ and depersonalisation $(\mathrm{r}=, 320, \mathrm{p}<.001)$. 
Regression assumptions were tested before proceeding to the regression analysis. The skewness and kurtosis coefficients of the variables are between -2 and +2 , and these values indicate that the data show a normal distribution. In order to examine autocorrelation, which is the second assumption, the autocorrelation between the errors with the Durbin-Watson test was examined to show that the errors are independent from each other. The Durbin-Watson test result being around 2 shows that the errors are independent of each other. Tolerance and VIF values were calculated to test the linearity of the relationship between the independent variables and the dependent variable, which is another assumption. It has been determined that this assumption is also met when the tolerance value is above 0.1 and the VIF values are below 10. Finally, the scatter plot was examined and it was seen that the concurrency assumption was met.

Table 3. Simple linear regression analysis for investigating the power of childhood traumas in predicting dissociation, its sub-dimensions and depression

\begin{tabular}{|c|c|c|c|c|c|c|c|}
\hline Predicted Variable & Predictor Variable & B & St. Error & $\beta$ & $\mathrm{R}$ & $\mathrm{R}^{2}$ & $\mathrm{t}$ \\
\hline \multirow[t]{2}{*}{ Dissociation } & Constant & ,183 & 4,430 & & & & ,041 \\
\hline & CTQ Total &, 541 &, 110 & 267 & 267 & ,071 & $4,896 * *$ \\
\hline \multirow[t]{7}{*}{ Dissociation } & Constant &,- 216 & 7,140 & & & &,- 030 \\
\hline & Emotional abuse & 2,047 &, 553 & ,266 & & & $3,703 * *$ \\
\hline & Physical abuse &, 543 & 674 & ,056 & & & ,806 \\
\hline & Physical neglect & 193 & ,553 & 023 & & & ,348 \\
\hline & Emotional neglect &,- 128 & 491 &,- 022 & & &,- 262 \\
\hline & Sexual abuse &,- 127 & 355 &,- 022 & & &,- 357 \\
\hline & Minimization &,- 777 & ,993 &,- 060 & ,319 & 102 &,- 782 \\
\hline \multirow[t]{7}{*}{ Amnestic } & Constant & $-3,364$ & 1,982 & & & & $-1,697$ \\
\hline & Emotional abuse &, 516 & ,153 & 243 & & & $3,364 * *$ \\
\hline & Physical abuse & 262 & 187 & ,098 & & & 1,400 \\
\hline & Physical neglect & 142 & 154 & ,062 & & & ,928 \\
\hline & Emotional neglect & ,004 & 136 & 003 & & & ,031 \\
\hline & Sexual abuse &,- 091 & ,099 &,- 057 & & &,- 928 \\
\hline & Minimization & ,151 & ,276 & ,042 & ,306 & ,093 &, 546 \\
\hline \multirow[t]{7}{*}{ Absorption } & Constant & 4,453 & 2,865 & & & & 1,554 \\
\hline & Emotional abuse & ,672 & ,222 & 223 & & & $3,029 * *$ \\
\hline & Physical abuse &,- 054 & 270 &,- 014 & & &,- 198 \\
\hline & Physical neglect & 071 & 222 & ,022 & & & ,318 \\
\hline & Emotional neglect &,- 105 & 197 &,- 045 & & &,- 531 \\
\hline & Sexual abuse & ,024 & 142 & 011 & & & ,170 \\
\hline & Minimization &,- 276 & 399 &,- 054 & ,233 & ,054 &,- 692 \\
\hline \multirow[t]{7}{*}{ Depersonalisation } & Constant & $-2,642$ & 1,802 & & & & $-1,466$ \\
\hline & Emotional abuse &, 508 &, 139 & 257 & & & $3,640 * *$ \\
\hline & Physical abuse & ,195 & , 170 & ,079 & & & 1,148 \\
\hline & Physical neglect &,- 055 & 140 &,- 026 & & &,- 391 \\
\hline & Emotional neglect & ,021 & 124 & ,014 & & & ,168 \\
\hline & Sexual abuse & ,052 & ,090 & ,035 & & &, 576 \\
\hline & Minimization &,- 280 & 251 &,- 084 & 361 & ,131 & $-1,115$ \\
\hline
\end{tabular}

As it can be seen in Table 3, childhood traumas account for $0.7 \%$ of psychoform dissociation $\left(\mathrm{R}^{2}=.07\right.$, $\mathrm{F}(1,312)=23,966, \mathrm{p}<.001)$. Emotional abuse, together with other sub-dimensions account for $10 \%$ of psychoform dissociation (amnestic) $\left(\mathrm{R}^{2}=.10, \mathrm{~F}(6,307)=5,812, \mathrm{p}<.001\right)$. Emotional abuse, together with other sub-dimensions, account for $0.9 \%$ of psychoform dissociation (absorption) $\left(\mathrm{R}^{2}=.09\right.$, $\mathrm{F}(6,307)=5,276, \mathrm{p}<.001)$. Emotional abuse, together with other sub-dimensions, account for $0.5 \%$ of psychoform dissociation (depersonalisation) $\left(\mathrm{R}^{2}=.05, \mathrm{~F}(6,307)=2,947, \mathrm{p}<.001\right)$. 


\begin{tabular}{lcccccc}
\hline \hline \multicolumn{7}{l}{ Table 4. Differentiation in DES cut-off score based on Scores below and above 30 } \\
\hline \multicolumn{2}{c}{ Subset } & \multicolumn{2}{c}{ Superset } & \multicolumn{2}{c}{ Female t Test } \\
& $\mathrm{N}=243$ & $(\% 77.4)$ & $\mathrm{N}=71$ & $(\% 22.6)$ & $\mathrm{Sd}=312$ & $\mathrm{p}$ \\
\multicolumn{1}{l}{ Scale } & $\mathrm{Mean}$ & $\mathrm{SS}$ & $\mathrm{Mean}$ & $\mathrm{SS}$ & $\mathrm{t}$ & .000 \\
Emotional abuse & 9,88 & 1,83 & 11,22 & 2,66 & $-4,872$ & .000 \\
Physical abuse & 5,27 & 1,38 & 6,10 & 2,35 & $-3,698$ & .050 \\
Physical neglect & 5,96 & 1,76 & 6,48 & 2,46 & $-1,969$ & .002 \\
Emotional neglect & 11,25 & 2,62 & 12,39 & 3,07 & $-3,097$ & .104 \\
Sexual abuse & 5,90 & 2,61 & 6,52 & 3,43 & $-1,631$ & .005 \\
Minimization & 1,52 & 1,28 & 1,04 & 1,11 & 2,836 & .000 \\
CTQ Total & 38,27 & 7,02 & 42,72 & 10,17 & $-4,201$ & .663 \\
Depression & 13,26 & 8,64 & 12,70 & 8,52 &, 478 & .068 \\
Self-harm & 8,27 & 12,33 & 5,34 & 10,15 & 1,831 & .113 \\
Somatoform & 29,26 & 9,31 & 27,27 & 9,27 & 1,588 &
\end{tabular}

As it can be seen in Table 4, considering the differentiation of psychoform dissociation based on the cutoff score of 30, significant differences were detected in favour of superset of emotional abuse $(X=11.22$; $\mathrm{SD}=2.66, \mathrm{p}<.001)$, physical abuse $(\mathrm{X}=6.10 ; \mathrm{SD}=2.35, \mathrm{p}<.001)$, emotional neglect $(\mathrm{X}=12.39 ; \mathrm{SD}=$ 3.07, $\mathrm{p}<.001)$, minimization $(\mathrm{X}=1.04 ; \mathrm{SD}=1.11, \mathrm{p}<001)$ and CTQ total $(\mathrm{X}=42.72 ; \mathrm{SD}=10.17$, $\mathrm{p}<.001)$. In addition to these, the types of self-harming behaviours expressed by the participants were biting and scratching at skin $(n=48)$, cutting skin $(n=32)$, sticking needle $(n=32)$, preventing the healing of the wound (e.g. severing their shells) $(n=29)$, hair pulling $(n=14)$, head banging and punching self $(\mathrm{n}=9)$, burning of skin $(\mathrm{n}=8)$, taking poisonous substances $(\mathrm{n}=1)$.

\section{DISCUSSION, CONCLUSION \& SUGGESTIONS}

In this study, data analysis showed that experiences of childhood traumas had a significant correlation with dissociative experiences (psychoform dissociation) and somatoform dissociation in female university students. It also showed that female university students with dissociative experiences at pathological level that can be diagnosed with dissociative disorder report emotional abuse, physical abuse, emotional neglect and childhood traumas at higher rates than female university students with non-pathological dissociative experiences.

A considerable number of studies pointing out that traumatic experiences in childhood are associated with psychological problems that may also be observed in adulthood are available. These studies also report that biological sex may have a mediating role and reveal that women with childhood traumas have a higher risk of suffering from depression and self-harming behaviours compared to men (Abrams et al., 2019; Chen \& Gueta, 2016; Cutler \& Nolen-Hoeksema, 1991; Gallo et al., 2017; Giarratano et al., 2020; Messina \& Grella, 2006; Vallati et al., 2020). Despite the emphasis on this biological sex difference, there are also researchers who argue that depression is related to gender-role socialization, with little or no biological influence (McBride \& Bagby, 2006, Piccinelli \& Wilkinson, 2000). Also, there are some studies showing that there is no relationship between gender-role and depression (Arcand et al., 2020; Bromberger \& Matthews, 1996). Therefore, besides the gender roles that women adopt, the negative life events they are exposed to due to this gender-role seem important. For example, Hünler (2000) reported that female university students who perceive more discrimination show more depressive symptoms, Schmitt et.al. (2002) found that perceived discrimination also negatively affects well-being. In addition, according to Hünler (2000), the adoption of gender roles by women and the expectation of behaviours that are not suitable for this role can lead to depression (Hünler, 2000). The fact that the participants of this research are university students, therefore, does not conform to traditional gender roles. Accordingly, 
the purpose of the study was to evaluate the effect of childhood traumas experienced by undergraduate female students on self-harming behaviours, depression levels, psychoform dissociation and somatoform dissociation. In line with the primary purpose, the correlation between the childhood traumas and selfharming behaviours, depression, psychoform dissociation, somatoform dissociation was examined; whether childhood traumas vary based on the DES scale cut-off score, and the predictive effect of childhood traumas on dependent variables.

Various studies in the literature explicitly indicate the correlation between childhood traumas, psychoform dissociation and somatoform dissociation and it can be stated, with certainty, that childhood traumas are one of the most basic etiological elements of somatoform dissociation and psychoform dissociation (Bohn et al., 2013; Nijenhuis, 2001; Öztürk \& Şar, 2008; Waller et al., 2001). This study also found that childhood traumas had a significant correlation with psychoform dissociation and somatoform dissociation (Table 2). In this study, the predictive role of childhood traumas on psychoform dissociation, somatoform dissociation, self-harming behaviours and depression in female university students was investigated and it was found that childhood traumas predicted psychoform dissociation and somatoform dissociation. In addition, as an original finding in this study, a significant negative correlation was found between somatoform dissociation and psychoform dissociation. Dissociative experiences that are characterized by chronic childhood traumas that emerge at an early age can be evaluated under two categories: "somatoform dissociation" that is phenomenologically related to the body and "psychoform dissociation" involving the mind. During or after traumatic experiences, these trauma victims give somatization reactions that occur in the body or psychoform dissociation reactions that occur psychologically (Farina et al., 2011; Nijenhuis, 2001, 2009; Nijenhuis et al., 2003). In our study that supports these data, a negative and significant correlation was found between SDQ-20 that is used to measure somatoform dissociation and DES that is used as a measurement tool that evaluates psychoform dissociation (Table 2). In another study conducted with university students, a negative relationship was found between physical abuse and somatoform dissociation and this data is in line with the findings of our study (Sadeghi et al., 2017). The reason why it shows a negative relationship between childhood traumas and somatoform dissociation and a positive relationship with psychoform dissociation may be the difference between dissociative reactions of individuals to negative life experiences. Traumatized individuals try to cope with these negative life events by showing either mind level (psychoform dissociation) or somatic symptoms (somatoform dissociation) (Farina et al., 2011; Nijenhuis, 2009). In a study, which supports this view, conducted with a sample of university students, it has been clearly demonstrated that both forms of dissociative experiences (psychoform dissociation and somatoform dissociation) that can develop during or immediately after chronic childhood traumas that begin at an early age may not occur at the same time. In the same study, it was emphasized that individuals are less likely to endure negative life events by showing both psychoform and somatoform dissociative reactions (Farina et al., 2011). In this context, one of the psychoform or somatoform dissociations is usually at the forefront in cases of dissociative disorder (Öztürk, 2020b). A considerable number of studies in the literature focusing on the correlation between childhood traumas and those dissociative experiences and self-harming behaviours highlight those dissociative experiences play an intermediary role between selfharming behaviours and childhood traumas (Chaplo et al., 2015; Ford \& Gómez, 2015; Franzke, Wabnitz \& Catani, 2015). Among psychological trauma and self-harming behaviours, "dissociative experiences" are the main determinants in determining the frequency, severity and duration of traumatic experiences. Self-harming behaviours, which are closely related to dissociation, are mostly carried out to control the 
negative effects of traumatic experiences on emotions, thoughts and behaviours (Öztürk, 2020b; Polskaya \& Melnikova, 2020). There are many clinical studies reporting that childhood traumatic experiences and dissociative experiences are more common in psychiatric patients with self-harming behaviours compared to other patient groups (Noll et al., 2003; Öztürk, 2020b; Van der Kolk \& Van der Hart, 1995; Webermann et al., 2016). In our study, a significant correlation was found between self-harming behaviours and somatoform dissociation but any significant correlation with psychoform dissociation was not found. This result is vital in showing that self-harming behaviours may escalate with increasing somatoform dissociative experiences and in evaluating somatoform dissociation, as well as psychoform dissociation, as a factor in the emergence of self-harming behaviours (Table 2). In addition to this, according to another study showing a certain similarity with this study, Öztürk and Şar (2008) found that dissociative disorder cases with suicidal thoughts were diagnosed with somatization disorder more than dissociative disorder cases without suicidal thoughts. It is thought that it is a sign of the positive correlation between suicidal thoughts and somatization, which are closely related with self-harming behaviours.

Female university students with dissociative experiences at pathological level (those with a total DES score of 30 and above) that can be diagnosed with dissociative disorder report emotional abuse, physical abuse, emotional neglect and childhood traumas (CTQ total scores) at higher rates than female university students with non-pathological dissociative experiences (Table 4). Many studies that support these findings are available and it can be stated that emotional abuse and emotional neglect occur at statistically higher rates in individuals with dissociative experiences (Belli et al., 2017; Şar, Türk, \& Öztürk, 2019; Vogel et al., 2009; Watson et al., 2006). In this study, participants with pathological dissociative experiences represent $22.6 \%$ of the entire sample, which is vital for revealing the severity of dissociative reactions in the non-clinical population. Studies conducted with non-clinical samples report that pathological dissociative experiences occur at 5.9-29.0\% over a wide extension and our finding is consistent with the research in the literature (Chiu et al., 2016; Fung, Ho, \& Ross, 2018; Serrano-Sevillano et al., 2017; Şar, Türk, \& Öztürk, 2019).

As a result of their meta-analysis, Vonderlin et al. (2018) found that individuals with a history of child abuse got higher dissociation scores than individuals without such a history. Anxiety and depression seem more likely to occur in individuals with a history of child abuse (Olafson, 2014). Based on another metaanalysis study, it is reported that adults who were exposed to sexual and physical abuse in their childhood report high levels of depression, anxiety and distress (Lindert et al., 2014). Yet another meta-analysis study found that the probability of depression increased when they calculated the long-term outcomes of childhood trauma (Humphreys et al., 2020). Erdoğan et al. (2020) suggested that childhood traumas may be taken into evaluation in individuals with depression and concomitant attentiondeficit/hyperactivity disorder. Childhood traumas may be the underlying cause in patients with affective, anxiety, and somatoform disorders (Carlier et al., 2016). Somatoform disorders are an interesting way to determine adolescents suffering from abuse (Marquis et al., 2016).

When the correlations between the variables were examined, a predictive correlation was not found between childhood trauma and self-harming behaviours. Although childhood trauma is a predictor of self-harming behaviours, research results indicate that dissociation is more effective (Zoroglu et al., 2003). Another study demonstrates that dissociation serves as a mediator between childhood traumas and selfharming behaviours (Hoyos et al., 2019). Childhood traumas have also been shown to have an 
intermediary effect for internalized and externalized behaviour problems such as self-harming behaviours (Hébert et al., 2018). Based on the analysis of the collected data, the findings obtained for the correlation between psychoform dissociation, somatoform dissociation, depression and childhood trauma were found to be consistent with the literature. Dissociation is assigned higher scores in individuals who report child abuse (Bennet, 2016; Fung et al., 2019). Dissociation also increases the risk of revictimization in individuals with childhood abuse (Zamir et al., 2018). The main difference of this study according to other studies is that childhood traumas have a positive relationship with psychoform dissociation and a negative relationship with somatoform dissociation. Previous studies have found a largely positive relationship between childhood traumas and somatoform dissociation (Maaranen et al., 2004; Palmisano et al., 2018; Waller et al., 2001). Contrary to the previous studies, in this study, it is found that the negative relationship between childhood traumas and somatoform dissociation as it was carried out with participants from non-clinical (normal) population. Kate, Hopwood \& Jamieson (2019) determined that approximately $10 \%$ of 25,871 university students had pathological dissociation according to the data average of 66 studies' meta-analysis on dissociative experiences and dissociative disorders in the university population. Referring to the studies in Turkey conducted with university students, DES average score is varied between 12,12 and 24,30 , this rate, even though it is below 30 points which point to dissociative experiences in pathological levels, is indicative that dissociative experiences are used in subclinical levels in the process of coping with traumatic experiences of everyday life (Dalbudak et al., 2014; Öztürk, 2020b; Öztürk \& Şar, 2008; Şar et al., 2019). The fact that 77.4\% (243 people) of the participants in this study were below the DES total score average of 30 is the main indication that the majority of the sample belongs to a non-clinical population in terms of dissociative disorders.

On the other hand, as Brand (2012) highlighted the consequences of randomized clinical trials' metaanalysis, researchers who focused on complex trauma patients generally overlook polysymptomatic patients. Bradley et al. (2005) concluded $62 \%$ of the participants in their study excluded participants with current alcohol or alcohol use, whereas $46 \%$ excluded participants with suicidal ideation. In line with this conclusion, Brand (2012) drew attention to the possibility of excluding dissociative disorders patients from studies focusing on treatment approaches for survivors of childhood abuse. Depending on that, it can be said that gathering data from non-clinical dissociative disorders participants empower the insufficient points of relevant studies.

Certain limitations of the present study need to be mentioned. First, since the research universe is made up of 143,759 female students enrolled in any undergraduate program in education faculties in Turkey in the 2018-2019 academic year, participants (314 female students) do not fully represent the research universe. Furthermore, we have not assessed the participants' prior experience in using medication or somatoform and psychoform dissociation. Nonetheless, our findings suggest that clinicians should be sensitive to the possibility that early childhood trauma experiences in female university students may be an issue that needs to be addressed in the treatment and management of self-harm, psychoform dissociation and somatoform dissociation. As a result of the study, it is thought that future studies may study with participants from clinical samples, and investigate other variables such as attachment, child rearing styles and defense mechanisms to further understand the relationship between childhood trauma and adulthood psychiatric symptoms in female university students. 


\section{Practical Implication}

As stated earlier, in this study, it was found that childhood traumas predicted psychoform dissociation in adulthood, and emotional abuse predicted amnestic dissociation, absorption and psychoform dissociation. In addition, as an important practical contribution to the literature, a negative and significant relationship was found between psychoform dissociation and somatoform dissociation in this study. Dissociative disorders are one of the leading psychiatric disorders that develop after childhood traumas, and these disorders negatively affect the social adaptation of individuals, their perception of the environment, consciousness and attention, leading to interruptions in their psychological integrity. For this reason, it is extremely important that cases of dissociative disorder, which is a trauma-related psychiatric disease that is characterized by suicide attempts, self-harming behaviours, especially in adolescents and adults, are recognized by both clinicians and teachers, and directed to the relevant treatment centers. 


\section{REFERENCES}

Abrams, M., Milisavljević, M., \& Šoškić, A. (2019). Childhood abuse: Differential gender effects on mental health and sexuality. Sexologies, 28(4), e89-e96. https://doi.org/10.1016/i.sexol.2019.07.002

Arcand, M., Juster, R. P., Lupien, S. J., \& Marin, M. F. (2020). Gender roles in relation to symptoms of anxiety and depression among students and workers. Anxiety, Stress, \& Coping, 33(6), 661-674. https://doi.org/10.1080/10615806.2020.1774560

Aysev, A. S. \& Taner, Y. I. (2007). Çocuk ve ergen ruh sağhğ ve hastallklar [Child and adolescent mental health and diseases]. Golden Print.

Belli, H., Akbudak, M., Ural, C., Solmaz, M., Doğan, Z. \& Konkan, R. (2017). Is there a complex relation between social anxiety disorder, childhood traumatic experiences and dissociation? Nordic Journal of Psycbiatry, 71(1), 55-60. https://doi.org/10.1080/08039488.2016.1218050

Bennet, S. E. (2016). Childhood abuse, dissociation, and coping self-efficacy as predictors of non-suicidal self-injury. (Publication No. 10169286) [Doctoral dissertation, Wilmington University]. ProQuest Dissertations \& Theses Global.

Bernstein, D. P., Fink, L., Handelsman, L., Foote, J., Lovejoy, M., Wenzel, K., Sapareto, E., \& Ruggiero, J. (1994). Initial reliability and validity of a new retrospective measure of child abuse and neglect. The American Journal of Psychiatry, 151(8), 1132-1136. https://doi.org/10.1176/aip.151.8.1132

Bernstein, E. M., \& Putnam, F. W. (1986). Development, reliability, and validity of a dissociation scale. The Journal of Nervous and Mental Disease, 174(2), 727-735. https://doi.org/10.1097/00005053-198612000-00004

Bifulco, A., Brown, G. W., \& Adler, Z. (1991). Early sexual abuse and clinical depression in adult life. The British Journal of Psychiatry, 159(1), 115-122. https://doi.org/10.1192/bjp.159.1.115

Bildik, T., Somer, O., Kabukçu Başay, B., Başay, Ö., \& Özbaran, B. (2013). Kendine zarar verme davranış1 değerlendirme envanterinin Türkçe formunun geçerlik ve güvenilirlik çalışması [The validity and reliability of the Turkish version of the inventory of statements about self-injury]. Turkish Journal of Psychiatry, 24(1), 49-57. http://dx.doi.org/10.5080/u6901

Bohn, D., Bernardy, K., Wolfe, F., \& Häuser, W. (2013). The association among childhood maltreatment, somatic symptom intensity, depression, and somatoform dissociative symptoms in patients with fibromyalgia syndrome: a single-center cohort study. Journal of Trauma \& Dissociation, 14(3), 342-358. https://doi.org/10.1080/15299732.2012.736930.

Bradley, R., Greene, J., Russ, E., Dutra, L., \& Westen, D. (2005). A multidimensional meta-analysis of

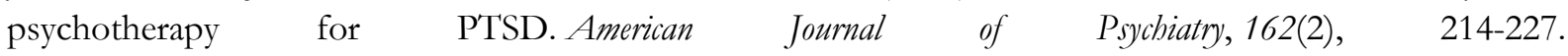
https://doi.org/10.1176/appi.ajp.162.2.214.

Brand, B. L. (2012). What we know and what we need to learn about the treatment of dissociative disorders. Journal of Trauma \& Dissociation, 13(4), 387-396. https://doi.org/10.1080/15299732.2012.672550.

Bromberger, J. T., \& Matthews, K. A. (1996). A “feminine" model of vulnerability to depressive symptoms: A longitudinal investigation of middle-aged women. Journal of Personality and Social Psychology, 70(3), 591. https://doi.org/10.1037/0022-3514.70.3.591

Carlier, I. V., Hovens, J. G., Streevelaar, M. F., van Rood, Y. R., \& van Veen, T. (2016). Characteristics of suicidal outpatients with mood, anxiety and somatoform disorders: the role of childhood abuse and neglect. International Journal of Social Psychiatry, 62(4), 316-326. https://doi.org/10.1177/0020764016629701.

Carr, S. N. \& Francis, A. J. (2010). Early maladaptive schemas and personality disorder symptoms: an examination in a non-clinical sample. Psychological Psychotherapy: Theory, Research and Practice, 83(4), 333-349. https://doi.org/10.1348/147608309X481351.

Chaplo, S. D., Kerig, P. K., Bennett, D. C., \& Modrowski, C. A. (2015). The roles of emotion dysregulation and dissociation in the association between sexual abuse and self-injury among juvenile justice-involved youth. Journal of Trauma \& Dissociation, 16(3), 272-285. https://doi.org/10.1080/15299732.2015.989647. 
Chen, G., \& Gueta, K. (2016). Gender differences in child abuse and intergenerational transmission of crime and substance abuse among Israeli inmates. Journal of Family Violence, 31(6), 735-746. https://doi.org/10.1007/s10896-016-9807-1.

Chiu, C. D., Paesen, L., Dziobek, I., \& Tollenaar, M. S. (2016). Weakened cognitive empathy in individuals with dissociation proneness. Journal of Social and Clinical Psychology, 35(5), 425-436. https://doi.org/10.1521/iscp.2016.35.5.425.

Cutler, S. E., \& Nolen-Hoeksema, S. (1991). Accounting for sex differences in depression through female victimization: Childhood sexual abuse. Sex Roles, 24(7-8), 425-438. https://doi.org/10.1007/BF00289332.

Dalbudak, E., Evren, C., Aldemir, S., \& Evren, B. (2014). The severity of Internet addiction risk and its relationship with the severity of borderline personality features, childhood traumas, dissociative experiences, depression and anxiety symptoms among Turkish university students. Psychiatry Research, 219(3), 577-582. https://doi.org/10.1016/i.psychres.2014.02.032.

Dozois, D. J. A., Martin, R. A., \& Bieling, P. J. (2009). Early maladaptive schemas and adaptive/maladaptive styles of humor. Journal of Cognitive Therapy and Research, 33: 585-596. https://doi.org/10.1007/s10608-008-9223-9.

Erdoğan, E., Delibaş, D. H., \& Baskin, E. P. (2020). Investigation of childhood traumas in inpatient adults with major depression and with or without attention deficit hyperactivity disorder comorbidity. Turkish J Clinical Psychiatry, 23, 56-63. https://doi.org/10.5505/kpd.2020.54765.

Farina, B., Mazzotti, E., Pasquini, P., \& Giuseppina Mantione, M. (2011). Somatoform and psychoform dissociation among women with orgasmic and sexual pain disorders. Journal of Trauma \& Dissociation, 12(5), 526-534. https://doi.org/10.1080/15299732.2011.598124.

Fischer, G., Gurris, N., Pross, C., \& Riedesser, P. (1996). Psychotraumatologie-Konzepte und spezielle Themenbereiche. Psychosomatische Medirin, 5, 543-552.

Fischer, S., Lemmer, G., Gollwitzer, M., \& Nater, U.M. (2014) Stress and resilience in functional somatic syndromes - a structural equation modeling approach. PLoS ONE, 9(11), e111214. https://doi.org/10.1371/journal.pone.0111214.

Fonagy, P. \& Allison, E. (2012). What is mentalization? The concept and its foundations in developmental research. In: N. Midgley \& I., Vrouva (Eds.), Minding the child: Mentalization-based interventions with children, young people and their families. (pp.11-34) Routledge Press.

Franzke, I., Wabnitz, P., \& Catani, C. (2015). Dissociation as a mediator of the relationship between childhood trauma and nonsuicidal self-injury in females: A path analytic approach. Journal of Trauma \& Dissociation, 16(3), 286-302. https://doi.org/10.1080/15299732.2015.989646.

Fung, H. W., Ho, L. Y. K., \& Ross, C. A. (2018). Pathological dissociation and its relationships with aggression and delinquency in a college student sample in Hong Kong. Journal of Aggression, Maltreatment \& Trauma, 27(2), 147-163. https://doi.org/10.1080/10926771.2017.1421283.

Fung, H. W., Ross, C. A., Yu, C. K. C., \& Lau, E. K. L. (2019). Adverse childhood experiences and dissociation among Hong Kong mental health service users. Journal of Trauma \& Dissociation, 20(4), 457-470. https://doi.org/10.1080/15299732.2019.1597808.

Gallo, E. A. G., De Mola, C. L., Wehrmeister, F., Gonçalves, H., Kieling, C. \& Murray, J. (2017). Childhood maltreatment preceding depressive disorder at age 18 years: A prospective Brazilian birth cohort study. Journal of Affective Disorders, 217, 218-224. https://doi.org/10.1016/i.jad.2017.03.065.

Giarratano, P., Ford, J. D., \& Nochajski, T. H. (2020). Gender differences in complex posttraumatic stress symptoms, and their relationship to mental health and substance abuse outcomes in incarcerated adults. Journal of Interpersonal Violence, 35(5-6), 1133-1157. https://doi.org/10.1177/0886260517692995.

Gören, S. ve Tiraşç1, Y. (2007). Çocuk istismarı ve ihmali [Child abuse and neglect]. Dicle Medical Journal, 34(1), 7074. http://www.diclemedj.org/upload/sayi/54/Dicle\%20Med\%20J-02602.pdf 
Haj-Yahia, M. M., \& Tamish, S. (2001). The rates of child sexual abuse and its psychological consequences as revealed by a study among Palestinian university students. Child Abuse \& Neglect, 25(10), 1303-1327. https://doi.org/10.1016/S0145-2134(01)00277-0.

Hébert, M., Langevin, R., \& Oussaïd, E. (2018). Cumulative childhood trauma, emotion regulation, dissociation, and behavior problems in school-aged sexual abuse victims. Journal of Affective Disorders, 225, 306-312. https://doi.org/10.1016/j.jad.2017.08.044.

Hisli, N. (1989). Beck Depresyon Envanterinin üniversite öğrencileri için geçerliği, güvenirliği [Validity and reliability of the Beck Depression Inventory for university students]. Turkish Journal of Psychology, 7(23), 3-13. https://toad.halileksi.net/sites/default/files/pdf/beck-depresyon-envanteri-toad.pdf

Hoyos, C., Mancini, V., Furlong, Y., Medford, N., Critchley, H., \& Chen, W. (2019). The role of dissociation and abuse among adolescents who self-harm. Australian \&o New Zealand Journal of Psychiatry, 53(10), 989-999. https://doi.org/10.1177/0004867419851869.

Humphreys, K. L., LeMoult, J., Wear, J. G., Piersiak, H. A., Lee, A., \& Gotlib, I. H. (2020). Child maltreatment and depression: A meta-analysis of studies using the Childhood Trauma Questionnaire. Child Abuse \& Neglect, 102, 104361. https://doi.org/10.1016/j.chiabu.2020.104361.

Hünler, O. S. (2000). Üniversite öğrencisi kadınlarda toplumsal cinsiyet ideolojisi ile depresyon ilişkisi [The relationship between gender role ideology and depression among female university students]. Kadin/Woman, $14(2), 39-53$.

Kahveci, S. (2016). Borderline Kişilik bozukluğunda zibin kuram ve çocukluk çă̆ travması arasindaki ilişki. (Yayıı No. 441642) [Yüksek lisans tezi, Üsküdar Üniversitesi]. Yüksek Öğretim Kurulu Başkanlığ1 Tez Merkezi.

Kara, B., Biçer, Ü. \& Gökalp, A. S. (2004). Çocuk istismarı [Child abuse]. Çocuk Sağlı̆̆ı ve Hastalıklar Dergisi, 47(2), 140-51.

Kate, M. A., Hopwood, T., \& Jamieson, G. (2019). The prevalence of Dissociative Disorders and dissociative experiences in college populations: a meta-analysis of 98 studies. Journal of Trauma \& Dissociation, 21(1),1661. https://doi.org/10.1080/15299732.2019.1647915.

Kepenekçi, Y. (2001). Hukuksal açıdan çocuk istismarı ve ihmali [Legal aspect of child abuse and neglect]. Katke Pediatri Dergisi, 22, 262-275.

Klonsky, E. D., \& Glenn, C. R. (2009). Assessing the functions of non-suicidal self-injury: Psychometric properties of the Inventory of Statements About Self-injury (ISAS). Journal of Psychopathology and Behavioral Assessment, 31(3), 215-219. https://doi.org/10.1007/s10862-008-9107-z.

Lindert, J., von Ehrenstein, O. S., Grashow, R., Gal, G., Braehler, E., \& Weisskopf, M. G. (2014). Sexual and physical abuse in childhood is associated with depression and anxiety over the life course: systematic review and meta-analysis. International Journal of Public Health, 59(2), 359-372. https://doi.org/10.1007/s00038-0130519-5.

Maaranen, P., Tanskanen, A., Haatainen, K., Koivumaa-Honkanen, H., Hintikka, J., \& Viinamäki, H. (2004). Somatoform dissociation and adverse childhood experiences in the general population. The Journal of Nervous and Mental Disease, 192(5), 337-342. https://doi.org/10.1097/01.nmd.0000126700.41047.83.

Marquis, C., Vabres, N., Caldagues, E., \& Bonnot, O. (2016). Clinic of somatoform disorders in abused adolescents. Presse Medicale (Paris, France: 1983), $45(4 \quad$ Pt 1$)$ e $51-8$. https://doi.org/10.1016/j.lpm.2015.10.023

Marylène, C., Lisa, R. C. \& Lisa, R. C. (2006). Sources of emotional maltreatment and the differential development of unconditional and conditional schemas. In M.C. McCarthy, M.N. Lumley (Eds). Treating survivors of childhood abuse: Psychotherapy for the interrupted life. (pp: 288-297). Guilford Press.

McBride C. \& Bagby R.M. (2006). Rumination and interpersonal dependency: Explaining women's vulnerability to depression. Canadian Psychology/ Psychologie Canadienne, 47(3), 184-194. https://psycnet.apa.org/doi/10.1037/cp2006008 
McCarthy, M. \& Lumley M. N. (2012). Sources of emotional maltreatment and the differential development of unconditional and conditional schemas. Cognitive Behaviour Therapy, 41(4), 288-297. https://doi.org/10.1080/16506073.2012.676669.

Merckelbach, H., \& Muris, P. (2001). The causal link between self-reported trauma and dissociation: A critical review. Behav Res Ther, 39(3),245-54. https://doi.org/10.1016/s0005-7967(99)00181-3

Messina, N., \& Grella, C. (2006). Childhood trauma and women's health outcomes in a California prison population. American Journal of Public Health, 96(10), 1842-1848. https://ajph.aphapublications.org/doi/epub/10.2105/AJPH.2005.082016

Nijenhuis, E. R. S. (2001). Somatoform dissociation: Major symptoms of dissociative disorders. Journal of Trauma \& Dissociation, 1(4), 7-32. https://doi.org/10.1300/J229v01n04 02.

Nijenhuis E. R. S. (2009). Somatoform dissociation and somatoform dissociative disorders. In P. F. Dell \& J.A. O'Neil (Eds.), Dissociation and the dissociative disorders: DSM-V and beyond. (pp.259-276). Routledge.

Nijenhuis, E. R. S., Spinhoven, P., Van Dyck, R., Van Der Hart, O., \& Vanderlinden, J. (1996). The development and psychometric characteristics of the Somatoform Dissociation Questionnaire (SDQ-20). Journal of Nervous and Mental Disease, 184(11), 688-694. https://doi.org/10.1097/00005053-199611000-00006.

Nijenhuis, E. R. S., Spinhoven, P., van Dyck, R., van der Hart, O., \& Vanderlinden, J. (1998). Psychometric Characteristics of the Somatoform Dissociation Questionnaire: A Replication Study1. Psychotherapy and Psychosomatics, 67(1), 17-23. https://doi.org/10.1159/000012254.

Nijenhuis, E. R. S., Van Dyck, R., Ter Kuile, M. M., Mourits, M. J. E., Spinhoven, P., \& Van der Hart, O. (2003). Evidence for associations among somatoform dissociation, psychological dissociation and reported trauma in patients with chronic pelvic pain. Journal of Psychosomatic Obstetrics \& Gynecology, 24(2), 87-98. https://doi.org/10.3109/01674820309042806.

Noll, J. G., Horowitz, L. A., Bonanno, G. A., Trickett, P. K., \& Putnam, F. W. (2003). Revictimization and selfharm in females who experienced childhood sexual abuse: Results from a prospective study. Journal of Interpersonal Violence, 18(12), 1452-1471. https://doi.org/10.1177/0886260503258035.

Ogrodniczuk, J. S., Joyce, A. S., \& Abbass, A. A. (2014). Childhood maltreatment and somatic complaints among adult psychiatric outpatients. Psychotherapy and Psychosomatics, 83(5), 322-324. https://doi.org/10.1159/000363769.

Olafson, E. (2014). Child sexual abuse: Demography, impact, and interventions. Journal of Child \& Adolescent Trauma, 4(1), 8-21. https://doi.org/10.1080/19361521. 2011.545811.

Özen, Ş., Antar, S., \& Özkan, M. (2007). Çocukluk çağı travmalarının umutsuzluk, sigara ve alkol kullanımı üzerine etkisi: Üniversite son sınıf öğrencilerini inceleyen bir çalşsma [Influence of childhood traumas on hopelessness, smoking and alcohol use: a study to evaluate last [year] university students]. Dusunen Adam The Journal of Psychiatry and Neurological Sciences, 20(2), 79-87.

Öztürk, E. (2004). Psikoterapide travmatik kendilik ve kendileşme [Traumatic self and getting himself/ herself in psychotherapy]. VIII. Annual Spring Conference of the Psychiatric Association of Turkey. pp.55-57, 14-18 April, Antalya.

Öztürk, E., \& Sar, V. (2008). Somatization as a predictor of suicidal ideation in dissociative disorders. Psychiatry and Clinical Neurosciences, 62(6), 662-668. https://doi.org/10.1111/j.1440-1819.2008.01865.x.

Öztürk, E. (2016). Psikotarih açısından çocuk yetiştirme tarzları ve çocuk istismarı [Child rearing modes (styles) with regards to psychohistory and child abuse]. F. Aşıcıŏlu ve N. Ziyalar, (Ed). in Forensic Behavioural Sciences (pp.24-34). Turkısh Clinics.

Öztürk, E. (2018). Travma Merkezli Alyans Model Terapi: Dissosiyatif Kimlik Bozukluğunun Psikoterapisi [Trauma Based Alliance Model Therapy: Psychotherapy of Dissociative Identity Disorder]. E. Öztürk, (Ed.), in Psychological Tramma and Dissociation (pp.31-38). Turkısh Clinics.

Öztürk, E. (2020a). Psikotarih, travma ve dissosiyasyon: Çocukluk çağı travmaları, savaşlar ve dissosiyasyonun anamnezi [Psychohistory, trauma and dissociation: The anamnesis of the childhood traumas, wars and dissociation]. E. Öztürk, (Ed.), in Psychohistory (pp.1-21). Turkısh Clinics. 
Öztürk, E. (2020b). Travma ve dissosiyasyon: Psikotravmatoloji temel kitabı (2. Bask1) [Trauma and dissociation: Psychotraumatology basic book]. Nobel Tip Kitabevi.

Palmisano, G. L., Innamorati, M., Susca, G., Traetta, D., Sarracino, D., \& Vanderlinden, J. (2018). Childhood traumatic experiences and dissociative phenomena in eating disorders: Level and association with the severity of binge eating symptoms. Journal of Trauma \& Dissociation, 19(1), 88-107. https://doi.org/10.1080/15299732.2017.1304490.

Piccinelli, M., \& Wilkinson, G. (2000). Gender differences in depression. Critical Review. British Journal of Psychiatry, 177, 486-492.

Polskaya, N. A., \& Melnikova, M. A. (2020). Dissociation, Trauma and Self-Harm. Counseling Psychology and Psychotherapy, 28(1), 25-48. https://doi.org/10.17759/cpp.2020280103.

Sadeghi, S., Dolatshahi, B., Pourshahbaz, A., Zarei, M., \& Kami, M. (2017). Relationship between traumatic experiences and somatic symptoms severity in students. Practice in Clinical Psychology, 5(3), 211-216. https://doi.org/211-216.10.18869/acadpub.jpcp.5.3.211

Schmitt, M., T., Branscombe, N., R., Kobrynowicz, D., \& Owen, S. (2002). Perceiving discrimination against one's gender group has different implications for wellbeing in women and men. Personality \& Social Psychology Bulletin, 28, 197-210. https://doi.org/10.1177\%2F0146167202282006

Serrano-Sevillano, Á., González-Ordi, H., Corbí-Gran, B., \& Vallejo-Pareja, M. Á. (2017). Psychological characteristics of dissociation in general population. Clinica y Salud, 28(3), 101-106. https://doi.org/10.1016/j.clysa.2017.09.003.

Shin, L. M., McNally, R. J., Kosslyn, S. M., Thompson, W. L., Rauch, S. L., Alpert, N. M., ... \& Pitman, R. K. (1999). Regional cerebral blood flow during script-driven imagery in childhood sexual abuse-related PTSD: a PET investigation. American Journal of Psychiatry, 156(4), 575-584. https://doi.org/10.1176/ajp.156.4.575.

Stein, M. B., Walker, J. R., Anderson, G., Hazen, A. L., Ross, C. A., Eldridge, G., \& Forde, D. R. (1996). Childhood physical and sexual abuse in patients with anxiety disorders and in a community sample. The American Journal of Psychiatry, 153 (2), 275-277. https://doi.org/10.1176/ajp.153.2.275.

Şar, V., Kundakci, T., Kiziltan, E., Bakim, B., \& Bozkurt, O. (2001). Differentiating dissociative disorders from other diagnostic groups through somatoform dissociation in Turkey. Journal of Trauma \& Dissociation, 1(4), 67-80. https://doi.org/10.1300/J229v01n04 04.

Şar, V., Öztürk, E., İkikardeş, E. (2012). Çocukluk Çağı Ruhsal Travma Ölçeğinin Türkçe uyarlamasının geçerlilik ve güvenirliği [Validity and reliability of the Turkish version of Childhood Trauma Questionnaire]. Turkiye Klinikleri Journal of Medical Sciences, 32(4), 1054-1063. doi: https://doi.org/10.5336/medsci.2011-26947.

Şar, V., Türk, T., \& Öztürk, E. (2019). Fear of happiness among college students: The role of gender, childhood psychological trauma, and dissociation. Indian Journal of Psychiatry, 61(4), 389. https://doi.org/10.4103/psychiatry.IndianJPsychiatry 5217.

Terock, J., Van der Auwera, S., Janowitz, D., Spitzer, C., Barnow, S., Miertsch, M., ... Grabe, H.-J. (2016). From Childhood Trauma to Adult Dissociation: The Role of PTSD and Alexithymia. Psychopathology, 49(5), 374 382. https://doi.org/10.1159/000449004

Tunç, P. (2019). Üniversite öğrencilerinde çocukluk çağı travması ve yeme tutumları ilişkisi [Childhood trauma and eating attitudes in university students]. Current Approaches in Psychiatry, 11(1), 203-219. https://doi.org/10.18863/pgy.612616.

Türksoy, N. (2003). Psikolojik travma ve tanm sorunlar, psikolojik travma ve sonuclar [Psychological trauma and definition problems, psychological trauma and its consequences]. 5US Publication.

Vallati, M., Cunningham, S., Mazurka, R., Stewart, J. G., Larocque, C., Milev, R. V., Bagby, R. M., Kennedy, S. H., \& Harkness, K. L. (2020). Childhood maltreatment and the clinical characteristics of major depressive disorder in adolescence and adulthood. Journal of Abnormal Psychology, 129(5), 469-479. https://doi.org/10.1037/abn0000521. 
Van der Hart, O., \& Horst, R. (1989). The dissociation theory of Pierre Janet. Journal of Traumatic Stress, 2(4), 397412. https://doi.org/10.1002/jts.2490020405.

Van der Kolk, B. A., \& Van der Hart, O. (1995). The intrusive past: The flexibility of memory and the engraving of trauma. In C. Caruth. (pp. 158-182). Trauma: Explorations in memory. The Johns Hopkins University Press.

Vogel, M., Spitzer, C., Kuwert, P., Möller, B., Freyberger, H. J., \& Grabe, H. J. (2009). Association of childhood neglect with adult dissociation in schizophrenic inpatients. Psychopathology, 42(2), 124-130. https://doi.org/10.1159/000204763.

Vonderlin, R., Kleindienst, N., Alpers, G. W., Bohus, M., Lyssenko, L., \& Schmahl, C. (2018). Dissociation in victims of childhood abuse or neglect: A meta-analytic review. Psychological Medicine, 48(15), 2467-2476. https://doi.org/10.1017/S0033291718000740.

Waldinger, R. J., Schulz, M. S., Barsky, A. J., \& Ahern, D. K. (2006). Mapping the road from childhood trauma to adult somatization: the role of attachment. Psychosomatic Medicine, 68(1), 129-135. https://doi.org/10.1097/01.psy.0000195834.37094.a4.

Waller, G., Hamilton, K., Elliott, P., Lewendon, J., Stopa, L., Waters, A., ... \& Chalkley, J. (2001). Somatoform dissociation, psychological dissociation, and specific forms of trauma. Journal of Trauma \& Dissociation, 1(4), 81-98. https://doi.org/10.1300/J229v01n04 05.

Watson, S., Chilton, R., Fairchild, H., \& Whewell, P. (2006). Association between childhood trauma and dissociation among patients with borderline personality disorder. Australian \& New Zealand Journal of Psychiatry, 40(5), 478-481. https://doi.org/10.1080/j.1440-1614.2006.01825.x.

Webermann, A. R., Myrick, A. C., Taylor, C. L., Chasson, G. S., \& Brand, B. L. (2016). Dissociative, depressive, and PTSD symptom severity as correlates of non-suicidal self-injury and suicidality in dissociative disorder patients. Journal of Trauma \& Dissociation, 17(1), 67-80. https://doi.org/10.1080/15299732.2015.1067941.

Yargic, L. I., Tutkun, H., \& Sar, V. (1995). Reliability and validity of the Turkish version of the Dissociative Experiences Scale. Dissociation: Progress in the Dissociative Disorders, 8(1), 10-13.

Young, J.E., Klosko, J.S. \& Weishaar, M.E. (2003). Şema terapi. (Çev.: T.V. Soylu,). Litera Yayınc1lı.

Zamir, O., Szepsenwol, O., Englund, M. M., \& Simpson, J. A. (2018). The role of dissociation in revictimization across the lifespan: A 32-year prospective study. Child Abuse \& Neglect, 79, 144-153. https://doi.org/10.1016/j.chiabu.2018.02.001.

Zoroglu, S. S., Tuzun, U., Sar, V., Tutkun, H., Savaçs, H. A., Ozturk, M., ... \& Kora, M. E. (2003). Suicide attempt and self-mutilation among Turkish high school students in relation with abuse, neglect and dissociation. Psychiatry and Clinical Neurosciences, 57(1), 119-126. https://doi.org/10.1046/j.1440-1819.2003.01088.x. 


\section{About Authors}

Eda Ermağan-Çağlar. She completed her undergraduate education in the field of Guidance and Psychological Counseling at Istanbul University in 2007. Afterwards, she completed her master's and doctorate degree in the field of Forensic Social Sciences at Istanbul University. She works as a psychological counsellor at the Embassy of Turkey in North Nicosia. In addition to this, as an assistant professor, she delivers lectures on forensic psychology and trauma psychology at University of Northampton and Beykoz University.

Erdinç Öztürk. He completed his undergraduate education at Istanbul University, Psychology Department in 1992. He received his Master's degree in the field of Clinical Psychology at Istanbul University in 1995. He received doctorate degree in the field of Forensic Sciences at Istanbul University in 2003. He is still working as a professor at Istanbul University-Cerrahpaşa, Institute of Forensic Sciences and Legal Medicine, Social Sciences Department.

Görkem Derin. He completed his undergraduate education at Istanbul University, Psychology Department in 2015. He received his Master's degree in the field of Social Sciences, Institute of Forensic Sciences and Legal Medicine at Istanbul University in 2018. He is a PhD candidate at the Department of Social Sciences, Forensic Sciences and Legal Medicine at Istanbul University-Cerrahpaşa. He is still working as a research assistant at Istanbul University-Cerrahpaşa, Institute of Forensic Sciences and Legal Medicine, Social Sciences Department.

Tuğba Türk-Kurtça. She completed her undergraduate education at Istanbul University, Psychological Counseling and Guidance in 2010. She received her Master's degree in the field of Psychological Services in Education at Istanbul University in 2013. She received his doctorate degree in the field of Psychological Counseling and Guidance at Marmara University in 2018. She is still working as an research assistant at Trakya University, Psychological Counseling and Guidance Department.

\section{Author Contributions}

This study was conducted by all the authors working together and cooperatively. All of the authors substantially contributed to this work in each step of the study.

\section{Conflict of Interest}

It has been reported by the authors that there is no conflict of interest.

\section{Funding}

This work was not financially supported.

\section{Ethical Statement}

The authors declare that they continue to work in accordance with scientific study ethics and the Helenski declaration in this study. Accordingly, the research was reviewed by the Trakya University Ethics Committee of the Social and Humanities Research and was given permission (Date: 23/01/2019, Number: 2019.01.03). In addition, the participants participated in the study on a voluntary basis.

Ethics Committee Name: Social and Human Sciences Research Ethics Committee of Trakya University.

Approval Date: 23/01/2019

Approval Document Number: E- 303358 - 29563864-050.04.04 